\title{
Boron incorporation in the foraminifer Amphistegina lessonii under a decoupled carbonate chemistry
}

\author{
K. Kaczmarek ${ }^{1}$, G. Langer ${ }^{2}$, G. Nehrke ${ }^{1}$, I. Horn ${ }^{3}$, S. Misra ${ }^{2}$, M. Janse ${ }^{4}$, and J. Bijma ${ }^{1}$ \\ ${ }^{1}$ Alfred-Wegener-Institut Helmholtz-Zentrum für Polar- und Meeresforschung, \\ am Handelshafen 12, 27570 Bremerhaven, Germany \\ ${ }^{2}$ Department of Earth Science, University of Cambridge, Dowing Site, CB2 3EQ Cambridge, UK \\ ${ }^{3}$ Institute of Mineralogy, Leibniz University, Callin street 3, 30167 Hanover, Germany \\ ${ }^{4}$ Burgers Zoo, Antoon van Hooffplein 1, 6816 SH Arnhem, the Netherlands \\ Correspondence to: K. Kaczmarek (karina.kaczmarek@awi.de)
}

Received: 10 September 2014 - Published in Biogeosciences Discuss.: 5 December 2014

Revised: 24 February 2015 - Accepted: 28 February 2015 - Published: 18 March 2015

\begin{abstract}
A number of studies have shown that the boron isotopic composition $\left(\delta^{11} \mathrm{~B}\right)$ and the $\mathrm{B} / \mathrm{Ca}$ ratio of biogenic carbonates (mostly foraminifers) can serve as proxies for two parameters of the ocean's carbonate chemistry, rendering it possible to calculate the entire carbonate system. However, the $\mathrm{B}$ incorporation mechanism into marine carbonates is still not fully understood and analyses of field samples show species-specific and hydrographic effects on the B proxies complicating their application. Identifying the carbonate system parameter influencing boron incorporation is difficult due to the co-variation of $\mathrm{pH}, \mathrm{CO}_{3}^{2-}$ and $\mathrm{B}(\mathrm{OH})_{4}^{-}$. To shed light on the question which parameter of the carbonate system is related to the boron incorporation, we performed culture experiments with the benthic symbiont-bearing foraminifer Amphistegina lessonii using a decoupled $\mathrm{pH}-\mathrm{CO}_{3}^{2-}$ chemistry. The determination of the $\delta^{11} \mathrm{~B}$ and $\mathrm{B} / \mathrm{Ca}$ ratios was performed simultaneously by means of a new in situ technique combining optical emission spectroscopy and laser ablation MC-ICP-MS. The boron isotopic composition in the tests gets heavier with increasing $\mathrm{pH}$ and $\mathrm{B} / \mathrm{Ca}$ increases with increasing $\mathrm{B}(\mathrm{OH})_{4}^{-} / \mathrm{HCO}_{3}^{-}$of the culture media. The latter indicates that boron uptake of $A$. lessonii features a competition between $\mathrm{B}(\mathrm{OH})_{4}^{-}$and $\mathrm{HCO}_{3}^{-}$. Furthermore, the simultaneous determination of $\mathrm{B} / \mathrm{Ca}$ and $\delta^{11} \mathrm{~B}$ on single specimens allows for assessing the relative variability of these parameters. Among different treatments the $\mathrm{B} / \mathrm{Ca}$ shows an increasing variability with increasing boron concentration in the test whereas the variability in the isotope distribution is constant.
\end{abstract}

\section{Introduction}

The oceans' carbonate system comprises six co-varying parameters $\left(\left[\mathrm{CO}_{2}\right],\left[\mathrm{HCO}_{3}^{-}\right],\left[\mathrm{CO}_{3}^{2-}\right], \mathrm{pH}\right.$, total alkalinity (TA), and dissolved inorganic carbon (DIC)). Changes of the carbonate system caused by past changes in the atmospheric $p \mathrm{CO}_{2}$ can be reconstructed if at least two of these parameters are known. A number of studies have shown that the boron isotopic composition $\left(\delta^{11} \mathrm{~B}\right)$ and the $\mathrm{B} / \mathrm{Ca}$ ratio of biogenic carbonates (mostly foraminifers) may serve as proxies that can provide these two parameters.

In seawater boron $(\mathrm{B})$ mainly exists as boric acid $\left(\mathrm{B}(\mathrm{OH})_{3}\right)$ and borate $\left(\mathrm{B}(\mathrm{OH})_{4}^{-}\right)$. The isotopic composition and concentration of both species are $\mathrm{pH}$ dependent (Fig. 1). Since the $\mathrm{B}$ isotopic composition of biogenic carbonates precipitated at a certain $\mathrm{pH}$ value is similar to that of $\mathrm{B}(\mathrm{OH})_{4}^{-}$, Hemming and Hanson (1992) concluded that only $\mathrm{B}(\mathrm{OH})_{4}^{-}$is incorporated into biogenic carbonates. Therewith, the $\mathrm{B}$ isotopic composition can be used as a proxy to infer the $\mathrm{pH}$ that prevailed during the formation of the biogenic carbonate. However, several studies show a deviation between the B isotopic composition of the biogenic carbonates and $\mathrm{B}(\mathrm{OH})_{4}^{-}$of the sea water (Sanyal et al., 1996, 2001; Foster, 2008; Rae et al., 2011). This deviation is often explained by physiological processes like photosynthesis and respiration of symbionts (e.g. dinoflagellates) which modify the $\mathrm{pH}$ in the microenvironment around the foraminifera (Zeebe et al., 2003) leading to shifts in the B equilibria. Yet another explanation for the observed deviation is that not only $\mathrm{B}(\mathrm{OH})_{4}^{-}$is incorporated 

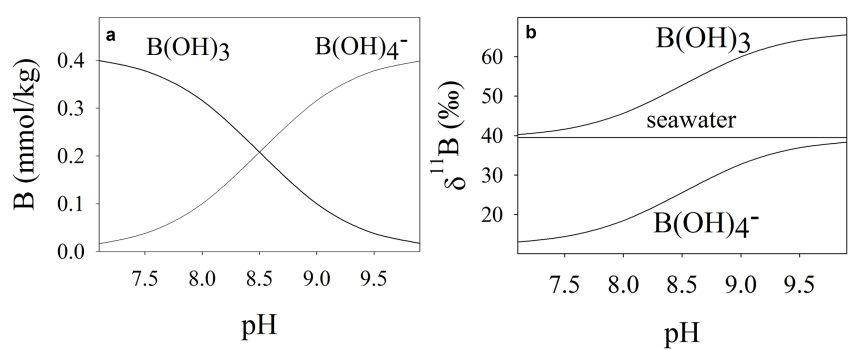

Figure 1. (a) Concentration of $\mathrm{B}(\mathrm{OH})_{3}$ and $\mathrm{B}(\mathrm{OH})_{4}^{-}$in seawater. (b) Isotopic composition of $\mathrm{B}(\mathrm{OH})_{3}, \mathrm{~B}(\mathrm{OH})_{4}^{-}$, and $\mathrm{B}$ in seawater. Graphs are plotted for $T=20^{\circ} \mathrm{C}$, $S=35, \quad P=380 \mu \mathrm{atm}, \quad[\mathrm{B}]=4.16 \mathrm{mmol} \mathrm{kg}^{-1}, \quad p K_{\mathrm{B}}=8.5$, $\alpha_{(\mathrm{B}(\mathrm{OH}) 3-\mathrm{B}(\mathrm{OH}) 4-)}=1.0272$.

during the formation of calcium carbonate but to some extent also the isotopically heavier $\mathrm{B}(\mathrm{OH})_{3}$ (Klochko et al., 2009). To account for physiological effects, species-specific calibration experiments have been carried out to be able to apply this proxy and reliably reconstruct seawater $\mathrm{pH}$ (Sanyal et al., 2001; Hönisch et al., 2003; Henehan et al., 2013).

While the $\mathrm{B}$ isotope composition of biogenic carbonates is used to reconstruct past seawater $\mathrm{pH}$, the $\mathrm{B} / \mathrm{Ca}$ of foraminiferal calcite is often used to infer past seawater $\mathrm{CO}_{3}^{2-}$ concentrations (e.g. Yu et al., 2007; Brown et al., 2011). Inherent to all field studies and most experimental studies is that $\mathrm{pH}$ and $\mathrm{CO}_{3}^{2-}$ concentration of natural seawater are correlated. It is therefore impossible to determine which parameter of the carbonate system is in control of $\mathrm{B} / \mathrm{Ca}$. Not surprisingly, correlations between $\mathrm{B} / \mathrm{Ca}$ and $\mathrm{pH}$ were described in addition to $\mathrm{B} / \mathrm{Ca}$ and $\mathrm{CO}_{3}^{2-}$ concentration (Yu et al., 2007; Tripati et al., 2011). The latter studies are based on field samples, but experimental studies suffer from the same ambiguity if the experimental setup uses a classical carbonate system manipulation, i.e. either DIC or TA manipulation. To identify the parameter of the carbonate system responsible for foraminiferal $\mathrm{B} / \mathrm{Ca}$, it is necessary to decouple $\mathrm{pH}$ and $\mathrm{CO}_{3}^{2-}$ concentration. Such an experimental setup will allow for excluding up to five out of the six parameters of the carbonate system. In an experimental study on the relationship between B / Ca and the seawater carbonate system Allen et al. (2012) showed "a competition between aqueous boron and carbonate species for inclusion into the calcite lattice" for Orbulina universa, Globigerinoides ruber, and Globigerinoides sacculifer. In this study we cultured A. lessonii under conditions in which $\mathrm{pH}$ and $\mathrm{CO}_{3}^{2-}$ concentration were decoupled in order to assess the controlling carbonate system parameter for B incorporation. The simultaneous determination of $\delta^{11} \mathrm{~B}$ and $\mathrm{B} / \mathrm{Ca}$ on single specimens by means of a newly developed technique (based on a femtosecond laser ablation MC-ICP-MS connected to a fibre optic spectrometer) allows for the first time the determination of the elemental and isotope B variability among single specimens.

\section{Material and methods}

\subsection{Culturing and experimental setup}

Live specimens of the benthic symbiont-bearing foraminifer A. lessonii were obtained from a coral reef aquarium at the Burgers Zoo (Arnhem, the Netherlands). SCUBA divers collected approximately $1 \mathrm{~kg}$ of sediment containing different species of foraminifers (Ernst et al., 2011). The sediment was transported to the Alfred Wegener Institute (Bremerhaven, Germany) immediately and transferred into a small aquarium $(5 \mathrm{~L})$ filled with filtered $(0.2 \mu \mathrm{m}$ pore-size $)$ North Sea seawater (NSW). The aquarium was equipped with a circulation pump to supply air and a time-switched light source providing a light/dark cycle $(12 \mathrm{~h} / 12 \mathrm{~h})$. About 100 specimens of A. lessonii were transferred to well plates containing NSW and placed in a temperature-controlled room at $25^{\circ} \mathrm{C}$ (again exposed to a $12 \mathrm{~h} / 12 \mathrm{~h}$ light/dark cycle). After 2 weeks $\sim 20 \%$ of the specimens had asexually reproduced, yielding 10-30 juveniles per specimen. Subsequently, juvenile foraminifers were transferred into Petri dishes containing NSW with a dedicated carbonate system (see Sect. 2.2. Preparation of culture media). Each Petri dish was placed into one of six boxes each receiving a concentration of $p \mathrm{CO}_{2}$ that was in equilibrium with the corresponding carbonate chemistry of the prepared NSW media. The supply of $p \mathrm{CO}_{2}$ was realized by a gas-mixing system producing a constant gas flow of $40 \mathrm{~L} \mathrm{~h}^{-1}$ for each box. Concentration of $\mathrm{CO}_{2}$ was logged using $\mathrm{CO}_{2}$ sensors (type FY0D00CO2B10 Ahlborn) and did not deviate by more than $25 \mu \mathrm{atm}$ from the targetvalue. In order to avoid evaporation of culture media in the Petri dishes, the gas was saturated with water by bubbling it through a fritted wash bottle filled with de-ionized water. The complete experimental setup was placed in a temperaturecontrolled $\left(25^{\circ} \mathrm{C}\right)$ room. Because of heat produced by the lamps the temperature within the boxes containing the Petri dishes increased by up to $2^{\circ} \mathrm{C}$ during the light cycle. Since this holds for all treatments, it did not impair the interpretation of results. Light intensity was $100-150 \mu \mathrm{mol}$ photons $\mathrm{m}^{-2} \mathrm{~s}^{-1}$. Every third day the culture media was replaced by a freshly opened aliquot from the corresponding batch of culture media, which was stored without headspace at $\sim 3^{\circ} \mathrm{C}$. Approximately $24 \mathrm{~h}$ before the culture media was replaced it was filled in a Petri dish and placed in the corresponding gas box to equilibrate. Each time when the culture media was replaced, foraminifers were fed with concentrated and sterilized algae Dunaliella salina $\left(20000\right.$ cells $\left.\mathrm{mL}^{-1}\right)$. Before feeding, algae were centrifuged to minimize dilution of the culture media, and exposed to $90^{\circ} \mathrm{C}$ for $20 \mathrm{~min}$ after centrifugation in order to reduce bacterial activity in the culture media. Foraminifers grew for 3 months. Afterwards specimens were harvested, bleached in $\mathrm{NaOCl}$ (active chlorine: $4.6 \%$ ) for 6 hours, rinsed four times using de-ionized water, and dried for $12 \mathrm{~h}$ at $50^{\circ} \mathrm{C}$. For laser ablation analysis 
specimens were mounted on a glass slide using double-sided adhesive tape.

Single, juvenile specimens of a clone were distributed equally between the different treatments to verify whether specimen-specific effects on $\delta^{11} \mathrm{~B}$ would occur which, however, were not observed after the B analysis. The size of all foraminifers ranged between 400 and $900 \mu \mathrm{m}$ before specimens were harvested. The morphology of the tests was indistinguishable from the one of specimens grown in the natural habitat (Fig. S1).

\subsection{Preparation of culture media}

Six treatments of manipulated NSW were prepared: treatments $1-4$ had a constant $\mathrm{pH}$ but different $\left[\mathrm{CO}_{3}^{2-}\right]$. The labels are as follows: $\mathrm{pH} \_8.1^{160}, \mathrm{pH} \_8.1^{260}, \mathrm{pH} \_8.1^{540}$ and $\mathrm{pH} \_8.1^{640}$. The exponent represents the concentration of $\mathrm{CO}_{3}^{2-}$ in $\mu \mathrm{mol} \mathrm{kg}{ }^{-1}$ respectively. We will refer to the sum of treatments $1-4$ as $\mathrm{pH} \_8.1 *$. Treatment 5 yields a $\mathrm{pH}$ of 8.56 and a $\mathrm{CO}_{3}^{2-}$ concentration of $638 \mu \mathrm{mol} \mathrm{kg} \mathrm{kg}^{-1}$. It is labelled as pH_8.6 $6^{640}$. Treatment 6 has a pH of 7.86 and a $\left[\mathrm{CO}_{3}^{2-}\right]$ of $268 \mu \mathrm{mol} \mathrm{kg} \mathrm{kg}^{-1}$. It is labelled as pH_7.9 $9^{260}$. Since our treatments are not in equilibrium with a $p \mathrm{CO}_{2}$ of $380 \mu \mathrm{atm}$ (except pH_8.1 $1^{260}$ ), we used a $\mathrm{CO}_{2}$ gas-mixing system providing each treatment with the associated equilibrium $p \mathrm{CO}_{2}$. The required manipulation of the culture media was calculated by means of the computer program octave and the file csys.m (created by Richard E. Zeebe and Dieter Wolf-Gladrow, downloadable at http://www.soest.hawaii.edu/oceanography/faculty/zeebe_

files/CO2_System_in_Seawater/csys.html). The csys.m file was modified to allow calculations of borate concentrations different from the natural concentration of seawater. The equilibrium constants of Mehrbach (for $K 1$ and $K 2$ ) and the total scale for $\mathrm{pH}$ were chosen. Temperature was set to $27^{\circ} \mathrm{C}$, salinity to 32 . Calculating the whole carbonate system chemistry requires at least two of its parameters. The input parameters for the $\mathrm{pH}$ constant treatments $\left(\mathrm{pH} \_8.1^{*}\right)$ were $\mathrm{pH}$ and $p \mathrm{CO}_{2}$, for the $\left[\mathrm{CO}_{3}^{2-}\right]$ constant treatments $\left(\mathrm{pH} \_8.6^{640}+\mathrm{pH} \_8.1^{640}\right.$ and $\left.\mathrm{pH} \_7.9^{260}+\mathrm{pH} \_8.1^{260}\right)$ $\left[\mathrm{CO}_{3}^{2-}\right]$ and $p \mathrm{CO}_{2}$. The basis for the different culture media was sterile filtered $(0.2 \mu \mathrm{m}$ pore size $) \mathrm{NSW}$ enriched in $\mathrm{B}$ (using $\mathrm{B}(\mathrm{OH})_{3}$ chemical purity: >99.5\%) to a final concentration of $\sim 4 \mathrm{mmol} \mathrm{kg}^{-1}$, which is $\sim 10$ times the $\mathrm{B}$ concentration of natural seawater. The enrichment with $\mathrm{B}$ was done to obtain a higher concentration within the test for better $\mathrm{B}$ analysis. For each treatment $2 \mathrm{~L}$ of culture media were prepared and filled without headspace into $50 \mathrm{~mL}$ (for the replacement of culture media) and $200 \mathrm{~mL}$ (for chemical analysis) gastight, boron free, silicate flasks and stored at $\sim 3{ }^{\circ} \mathrm{C}$.

\subsection{Analysis of the culture media}

Since the amount of culture media in the Petri dishes containing the foraminifers (which was replaced all 3 days) was not sufficient for all chemical analysis, approximately $200 \mathrm{~mL}$ of each batch of culture media were filled in polypropylene beakers and placed into the corresponding $\mathrm{CO}_{2}$ box to equilibrate. Even though determining the chemical parameters once would have been sufficient, we performed this procedure bi-weekly to verify that all conditions stayed constant during the experimental period. After $\sim 24 \mathrm{~h}$ salinity and $\mathrm{pH}$ of these solutions were measured at in situ conditions and samples were taken for $\mathrm{Ca}, \mathrm{B}$, DIC and TA analysis. Salinity measurements were performed using a conductivity meter (WTW Multi 340i) interfaced with a TetraCon 325 sensor. Measurements of $\mathrm{pH}$ were carried out by means of a combined $\mathrm{pH}$ glass electrode (Ectotrode Plus, Metrohm) interfaced with a Radiometer pH-Meter (PHM240). Repeated measurements of buffers show a reproducibility of $0.05 \mathrm{pH}$ units. After calibration (NBS buffer) the conversion to total scale was performed by measuring a Tris/Tris-HCl seawater buffer prepared in accordance with the recipe described in Dickson et al. (2007). Calcium and B concentrations were determined by a Thermo Elemental (TJA) IRIS Intrepid ICP-OES Spectrometer using Merck 4 (multi-element standard) as reference material. The average external error as estimated by multiple measurements of the reference material was $\pm 3.5 \%$. Total alkalinity was calculated from linear Gran plots (Gran, 1952) after triplicate potentiometric titration (Bradshaw et al., 1981) using a TitroLine alpha plus auto sampler (Schott Instruments). Culture media samples were calibrated against an in-house standard (NSW) which is calibrated regularly against certified reference material batch No. 54 of Dickson (Scripps Institution of Oceanography). The average reproducibility is $\pm 10 \mu \mathrm{mol} \mathrm{kg}{ }^{-1}$. Determination of DIC was performed photometrically in triplicates with a TRAACS CS800 QuaAAtro autoanalyser with an average reproducibility of $\pm 10 \mu \mathrm{mol} \mathrm{L}^{-1}$ based on calibrations of an in-house standard (NSW) calibrated against Certified Reference Material Batch No. 54 of Dickson (Scripps Institution of Oceanography). Boron isotopic composition of the culture media were analysed by means of a Thermo ${ }^{\circledR}$ Element XR, a single collector, sector field, high-resolution inductively coupled plasma mass spectrometer, fitted with a high-sensitivity interface pump (Jet pump) as described in Misra et al. (2014). Boron isotopic composition is reported as per mil (\%o) deviation from NIST SRM 951a $\left({ }^{11} \mathrm{~B} /{ }^{10} \mathrm{~B}=4.04362 \pm 0.00137\right)$ (Catanzaro et al., 1970) where

$\delta^{11} \mathrm{~B}_{\text {sample }}(\% o)=\left[\frac{\left({ }^{11 / 10} \mathrm{~B}\right)_{\text {sample }}}{\left({ }^{11 / 10} \mathrm{~B}\right)_{\text {NISTSRM 951a }}}-1\right] \times 1000$.

Boron isotope analyses were made following a SampleStandard Bracketing (SSB) technique. NIST 951a was used as the standard and samples were concentration matched, 
Table 1. Mean values of the B isotopic composition and B / Ca of A. lessonii. Errors are expressed as $\operatorname{SD}\left(\operatorname{SD}=\sqrt{\frac{\sum(\bar{x}-x)^{2}}{N}}\right.$, information about $N$ is given in the Supplement). Also listed are the calculated isotopic composition of $\mathrm{B}(\mathrm{OH})_{4}^{-}$(using Eq. (S3) and based on a calculated carbonate system using $\mathrm{pH}$ and $\mathrm{DIC}$ as input parameters) and the offset between the isotopic composition of foraminifers and $\mathrm{B}(\mathrm{OH})-{ }_{4}^{-}$ $\left(\Delta \delta^{11} \mathrm{~B}\right)$.

\begin{tabular}{|c|c|c|c|c|c|c|}
\hline Treatments & $\begin{array}{r}\delta^{11} \mathrm{~B} \\
(\% o)\end{array}$ & $\begin{array}{r} \pm \delta^{11} \mathrm{~B} \\
(\% \circ)\end{array}$ & $\begin{array}{r}\delta^{11} \mathrm{~B} \mathrm{~B}(\mathrm{OH}){ }_{4 \mathrm{cal}}^{-} \\
(\% \circ)\end{array}$ & $\begin{array}{r}\Delta \delta^{11} \mathrm{~B} \\
(\% \circ)\end{array}$ & $\begin{array}{r}\mathrm{B} / \mathrm{Ca} \\
\left(\mathrm{mmol} \mathrm{mol}^{-1}\right)\end{array}$ & $\begin{array}{r} \pm \mathrm{B} / \mathrm{Ca} \\
\left(\mathrm{mmol} \mathrm{mol}^{-1}\right)\end{array}$ \\
\hline pH_8.1 160 & -32.71 & 1.27 & -29.01 & 3.70 & 5.23 & 1.06 \\
\hline pH_8.1 ${ }^{260}$ & -31.88 & 1.20 & -28.81 & 3.07 & 2.95 & 0.53 \\
\hline pH_8.1 $1^{540}$ & -31.69 & 1.20 & -28.36 & 3.32 & 1.75 & 0.11 \\
\hline $\mathrm{pH} \_8.1^{640}$ & -32.45 & 1.43 & -28.59 & 3.86 & 1.58 & 0.12 \\
\hline pH_8.6 640 & -23.65 & 1.97 & -22.75 & 0.90 & 6.36 & 1.30 \\
\hline pH_7. $9^{260}$ & -35.59 & 1.22 & -31.34 & 4.25 & 1.20 & 0.08 \\
\hline
\end{tabular}

typically at $\pm 5 \%$, with the standard and were analysed in quintuplicate. The accuracy and precision of the analytical method was assessed by comparing $\delta^{11} \mathrm{~B}$ measurements of seawater (from the Atlantic Ocean) and secondary boron standards (AE 120, 121, 122) with published (accepted) results. Our estimate of $\delta^{11} \mathrm{~B}_{\mathrm{SW}}$ of $39.8 \pm 0.4 \%$ o $(2 \sigma, n=30)$ are independent of sample size and are in agreement with published values of 39.6 $\pm 0.4 \%$ (Foster et al., 2010) and $39.7 \pm 0.6 \%$ (Spivack and Edmond, 1987). Moreover, our $\delta^{11} \mathrm{~B}$ estimates of SRM AE-120 $(-20.2 \pm 0.5 \%$ o, $2 \mathrm{~s}, n=$ 33), SRM AE-121 (19.8 $\pm 0.4 \%$, $2 \mathrm{~s}, n=16)$, SRM AE-122 $(39.6 \pm 0.5 \%$ o, $2 \mathrm{~s}, n=16)$ are identical, within analytical uncertainty, to accepted values (Vogl and Rosner, 2012). Information about sample preparation for analysis can be found in the Supplement.

\subsection{Simultaneous determination of $B$ isotopic composition and $B$ concentration of single tests}

For the simultaneous determination of the B isotopic composition and B concentration a Fibre Optics Spectrometer (Maya2000 Pro, Ocean Optics) was connected to the torch of a Thermo Finnigan Neptune multiple-collector inductively coupled plasma mass spectrometer (MC-ICP-MS) at the Leibniz University of Hanover. Laser ablation on reference material, NISTSRM 610, and samples was performed by an in-house built UV-femtosecond laser ablation system based on a regenerative one-box femtosecond laser (SolsticSpectra Physics).

The measured intensity for B in a standard is related to its known concentration. Based on this relationship the unknown B concentration of a sample can be calculated. However, in our case measurements of the reference material (NISTSRM 610) and samples have not been performed at the same laser repetition rate, hence their B ratio is not proportional. The correction for different laser repetition rates can be realized using an optical spectrometer by the collection of $\mathrm{Ca}$ on the two high-intensity first-order emission lines of $\mathrm{Ca}$
II at 393.48 and $396.86 \mathrm{~nm}$ in cps. The detection of $\mathrm{Ca}$ intensities of NISTSRM 610 and samples (whose Ca concentrations are known: [Ca] of NISTSRM 610 is $8.45 \%$, [Ca] of $\mathrm{CaCO}_{3}$ is $40 \%$ ) makes it possible to correct for different laser repetition rates as described in Longerich et al. (1996). A detailed description of this methodology can be found in Kaczmarek et al. (2015). A brief summary of the method is given in the Supplement.

\section{Results and discussion}

\subsection{Carbonate system}

The determination of $\mathrm{pH}$, TA and DIC of the culture media yielded three parameters of the carbonate system. In theory, any two of these parameters can be used to calculate the entire carbonate system. However, it has been shown that the results can differ depending on the choice of input parameters (Hoppe et al., 2012). To evaluate in how far the choice of input parameters ( $\mathrm{pH} / \mathrm{DIC}$, DIC / TA, and $\mathrm{pH} / \mathrm{TA}$ ) would affect the calculated carbonate system within the same treatment, calculations have been performed with all three combinations of input parameters. As can be seen from Table S1 (in the Supplement) for this study the choice of input parameters does not result in significant differences. Therefore, further discussions and plots are based on the carbonate system calculated from the input parameters $\mathrm{pH}$ and DIC.

\subsection{The B isotopic signature of $A$. lessonii tests}

The measured boron isotopic composition of the foraminiferal tests is given in Table 1 (mean values calculated from single measurements of all foraminifers within one treatment) and Table S2 (single measurements of each foraminifer). For the treatments $\mathrm{pH}$ _8.1* the boron isotopic composition is identical $(\sim-32 \%$ o) while treatment pH_8.6 640 shows an increase of the boron isotopic composition by $8.5 \%$. The boron isotopic composition determined 

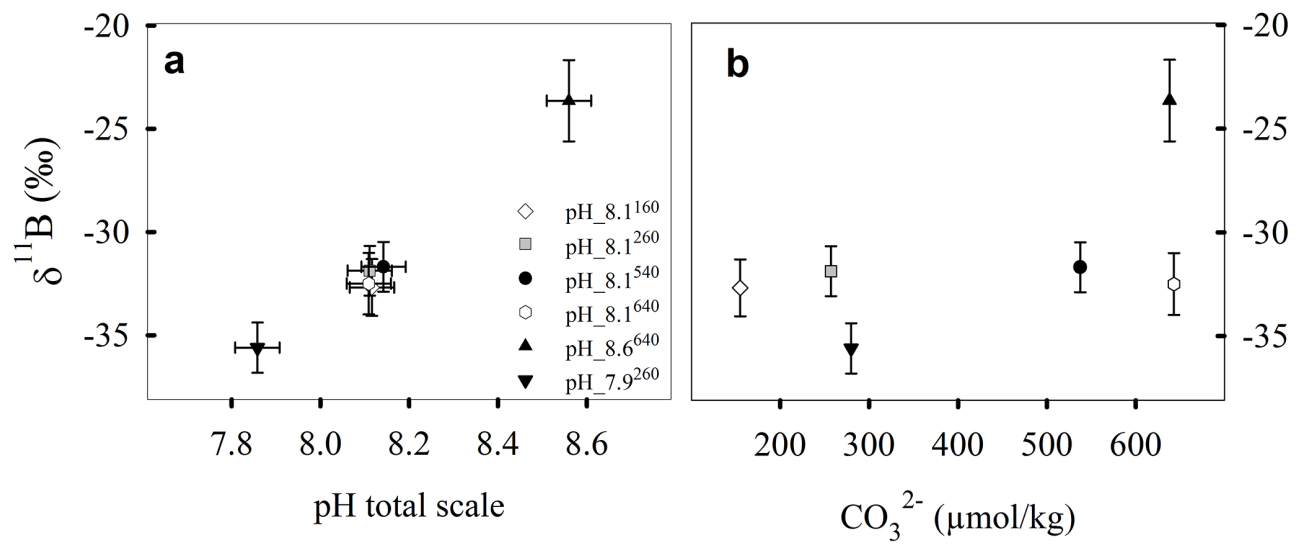

Figure 2. (a) Boron isotopic composition vs. $\mathrm{pH}$ of the culture media for all treatments. $\delta^{11} \mathrm{~B}$ data represent mean values obtained from single measurements within one treatment. Error bars for $\delta^{11} \mathrm{~B}$ represent SD. (b) Calculated carbonate ion concentration vs. $\mathrm{pH}$.

for treatment $\mathrm{pH} \_7.9^{260}$ shows a decrease of $3.4 \%$ compared to the values determined for the treatments $\mathrm{pH} \_8.1 *$. The results show that the boron isotopic signature is clearly related to $\mathrm{pH}$ and independent of the $\mathrm{CO}_{3}^{2-}$ concentration (Fig. 2).

Under the general assumption that $\mathrm{B}(\mathrm{OH})_{4}^{-}$is the only species incorporated into the test of foraminifers, $\delta^{11} \mathrm{~B}$ of the test should equal the $\delta^{11} \mathrm{~B}$ of $\mathrm{B}(\mathrm{OH})_{4}^{-}$. Therefore, theoretically the offset between both $\left(\delta^{11} \mathrm{~B}_{\text {foram }}-\delta^{11} \mathrm{~B}_{\mathrm{B}(\mathrm{OH}) 4-}\right)$ should be zero. Figure 3 shows the offset from the theoretical $\delta^{11} \mathrm{~B}$ of $\mathrm{B}(\mathrm{OH})_{4}^{-}$for each specimen and the interspecimen variability in $\delta^{11} \mathrm{~B}_{\text {foram }}$. It can be seen that most foraminifers grown at a $\mathrm{pH}$ of 7.9 and 8.1 show an offset towards more negative $\delta^{11} \mathrm{~B}$ values. Foraminifers grown at a $\mathrm{pH}$ of 8.6 are shifted towards more positive $\delta^{11} \mathrm{~B}$ values. The inter-specimen variability in $\delta^{11} \mathrm{~B}$ spans a range of $\sim 7 \%$ o for foraminifers within the same treatment (the standard deviation for one foraminifera ranges from 1.20 to $1.97 \%$, see Table 1). In the following we address two questions: (1) what causes the offset of $\delta^{11} \mathrm{~B}$ of foraminifers from the theoretical $\delta^{11} \mathrm{~B}$ of $\mathrm{B}(\mathrm{OH})_{4}^{-}$? (2) What are the potential reasons for the observed inter-specimen variability in $\delta^{11} \mathrm{~B}$ ?

\subsubsection{The offset from the theoretical $\delta^{11} B$}

\section{Test size}

It has been suggested that the $\delta^{11} \mathrm{~B}$ of foraminifers is related to its test size. Hönisch and Hemming (2004) report heavier $\delta^{11} \mathrm{~B}$ by 2.1 to $2.3 \%$ for individuals of Globigerinoides sacculifer in the sieve size class 515-865 $\mu \mathrm{m}$ than for shells in the $250-380 \mu \mathrm{m}$ size class. This observation is explained by a reduced photosynthetic activity in smaller specimens at greater depth. A study by Walker (2004) showed a linear increase between size and symbionts in A. lessonii. If larger foraminifers accommodate more symbionts, smaller foraminifers experience less symbiotic activity, which might

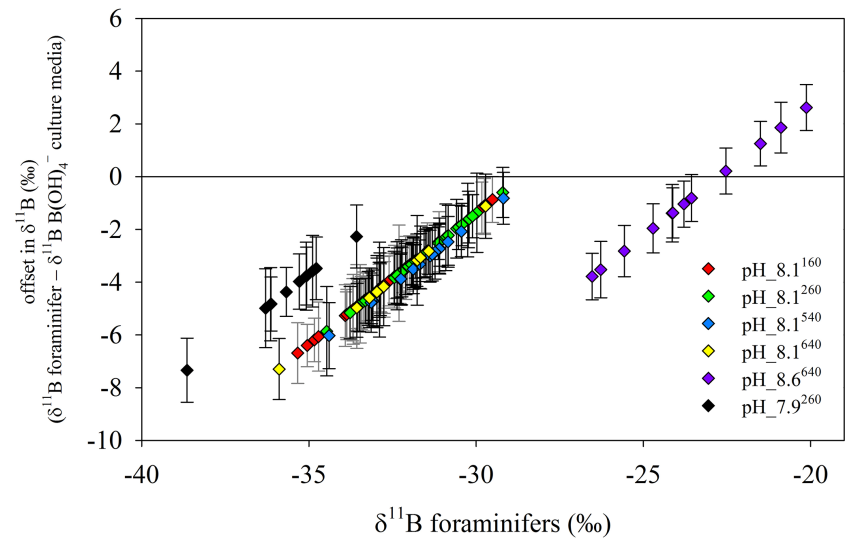

Figure 3. Difference between measured $\delta^{11} \mathrm{~B}$ in foraminifers and calculated $\delta^{11} \mathrm{~B}$ of $\mathrm{B}(\mathrm{OH})_{4}^{-}(y$-axis $)$ plotted against measured foraminiferal $\delta^{11} \mathrm{~B}$. The solid black line represents the $\mathrm{B}$ isotopic composition of $\mathrm{B}(\mathrm{OH})_{4}^{-}$. Error bars of single $\delta^{11} \mathrm{~B}$ values represent $2 \mathrm{RSE}$ and were calculated according to Eq. (S3) in the Supplement. The $\delta^{11} \mathrm{~B}$ of $\mathrm{B}(\mathrm{OH})_{4}^{-}$was calculated by Zeebe and Wolf-Gladrow (2001): $\delta^{11} \mathrm{~B}_{\mathrm{B}(\mathrm{OH})_{4}^{-}}=$ $\frac{\delta^{11} \mathrm{~B}_{\mathrm{CM}} \times\left[\mathrm{B}_{\mathrm{CM}}\right]-\varepsilon_{\mathrm{B}} \times\left[\mathrm{B}(\mathrm{OH})_{3}\right]}{\left[\mathrm{B}(\mathrm{OH})_{4}^{-}\right]+\alpha_{\mathrm{B}} \times\left[\mathrm{B}(\mathrm{OH})_{3}\right]}$, where $\delta^{11} \mathrm{~B}_{\mathrm{CM}}$ and $\left[\mathrm{B}_{\mathrm{CM}}\right]$ are the $\delta^{11} \mathrm{~B}$ and $\mathrm{B}$ concentration of the culture media, $\alpha_{\mathrm{B}}$ is the $\mathrm{B}$ isotope fractionation factor between $\mathrm{B}(\mathrm{OH})_{3}$ and $\mathrm{B}(\mathrm{OH})_{4}^{-}\left(\alpha_{\mathrm{B}}=1.0272\right.$; Klochko et al., 2006) and $\varepsilon=(\alpha-1) \times 1000$. In order to calculate $\Delta \delta^{11} \mathrm{~B}$ the isotopic difference between NIST 610 (reference material to determine $\delta^{11} \mathrm{~B}_{\text {foram }}$ ) and SRM 951 (reference material to determine $\delta^{11} \mathrm{~B}_{\mathrm{CM}}$ ) has to be taken into account. As shown by several studies (Kasemann et al., 2001; le Roux et al., 2004; Fietzke et al., 2010) both standards are within analytical uncertainty isotopically equal.

lead to lighter $\delta^{11} \mathrm{~B}$. However, in our study we do not observe either a correlation between the size of foraminifers and $\delta^{11} \mathrm{~B}$ or a correlation between growth rate and $\delta^{11} \mathrm{~B}$ (Fig. 4). In our experiment specimens grew for 3 months reaching a size 


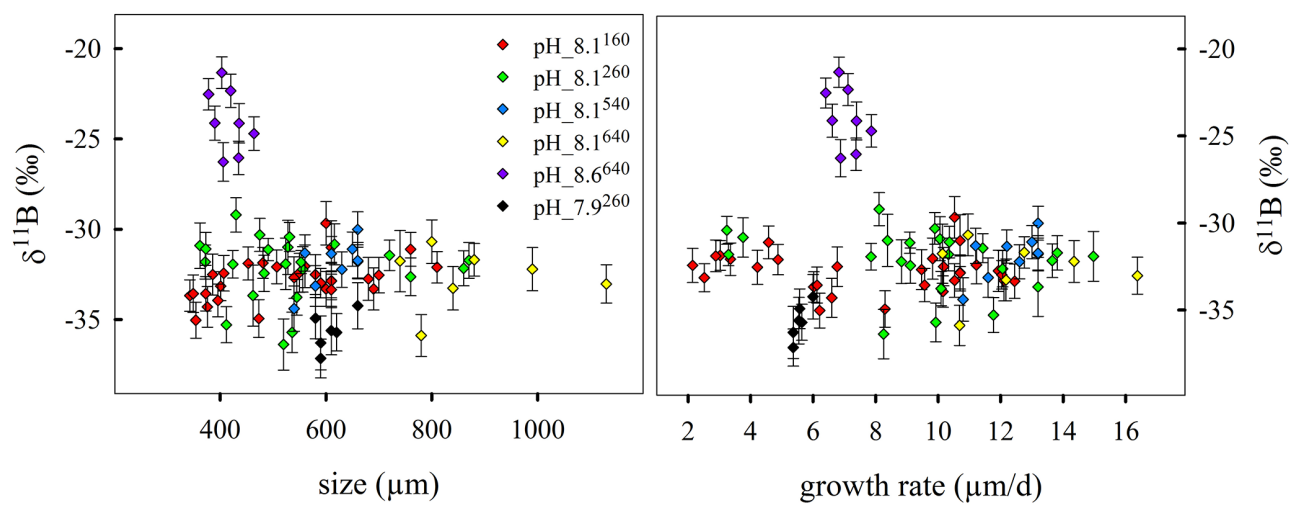

Figure 4. Size and growth rate (defined as final size divided by the number of days in culture) vs. B isotopic compositions of foraminifers. If a specimen was measured several times the mean $\delta^{11} \mathrm{~B}$ is presented here. Error bars of single $\delta^{11} \mathrm{~B}$ values represent 2RSE and were calculated according to Eq. (S3).

between 400 and $900 \mu \mathrm{m}$. Although we observed different growth rates within each treatment, we do not see a correlation between the test size and the boron isotopic composition. If such an effect really exists in A. lessonii, it is very small and not reflected in the boron isotopic composition.

\section{Vital effects}

For planktonic foraminifers symbiont activity strongly influences the $\mathrm{pH}$ in their microenvironment (Rink et al., 1998; Zeebe et al., 2003) affecting the $\delta^{11} \mathrm{~B}$ signature of the test. The photosynthetic activity of symbionts consumes $\mathrm{CO}_{2}$ leading to a $\mathrm{pH}$ increase while symbionts' respiration generates $\mathrm{CO}_{2}$ leading to a $\mathrm{pH}$ decrease within the microenvironment around the foraminifer. In theory, acidification of the microenvironment due to respiration and calcification would result in lighter $\delta^{11} \mathrm{~B}$ of the test whereas consumption of $\mathrm{CO}_{2}$ by photosynthesis leads to heavier $\delta^{11} \mathrm{~B}$. The net impact of these different processes depends on their respective rates (Zeebe et al., 2003). The effect of photosynthesis on $\delta^{11} \mathrm{~B}$ in two planktonic species of foraminifers was studied by Hönisch et al. (2003). Based on a comparison between the field grown, symbiont-bearing species Orbulina universa and the symbiont-barren Globigerina bulloides Hönisch et al. (2003) observed a lighter $\delta^{11} \mathrm{~B}$ for G. bulloides by $1.4 \%$. The authors suggested that if photosynthesis and respiration are the major processes causing deviations in foraminiferal $\delta^{11} \mathrm{~B}$, foraminifers with high symbiont activity (like $O$. universa) should record heavier $\delta^{11} \mathrm{~B}$ values whereas symbiontbarren foraminifers (like G. bulloides) should record lighter $\delta^{11} \mathrm{~B}$ values. In the same study Hönisch et al. (2003) also investigated the impact of symbionts on $\delta^{11} \mathrm{~B}$ within one species. From culture experiments with $O$. universa (using culture media with a similar B concentration as used in this study) the authors report $\delta^{11} \mathrm{~B}$ values to be $1.5 \%$ heavier under high-light than under low-light conditions. The impact of photosynthesis on $\delta^{11} \mathrm{~B}$ was also studied by Zeebe et al. (2003) based on a model approach which also includes the data of Hönisch et al. (2003). The diffusion-reaction model of Zeebe et al. (2003) describes changes in the carbonate chemistry and B equilibrium caused by vital effects in the microenvironment of $O$. universa. Based on this model changes in $\delta^{11} \mathrm{~B}$ due to different symbiont activities (as observed for high light and low light in the culture study of Hönisch et al., 2003) can be calculated. In general, the calculated changes in $\delta^{11} \mathrm{~B}$ are in good agreement with the changes observed in the cultured $O$. univers $a$. Furthermore, the model showed that the $\delta^{11} \mathrm{~B}$ of $O$. universa cultured at high light is heavier than the $\delta^{11} \mathrm{~B}$ of $\mathrm{B}(\mathrm{OH})_{4}^{-}$in the culture media, whereas at low light the opposite is reported. Amphistegina lessonii is a symbiont-bearing species. The $\delta^{11} \mathrm{~B}$ values of this species are lighter than those of $\mathrm{B}(\mathrm{OH})_{4}^{-}$, a fact which is seemingly at odds with the conclusions of Hönisch et al. (2003) and Zeebe et al. (2003). In order to shed light on the question whether symbiont activity may explain the lighter $\delta^{11} \mathrm{~B}$ values in our study (as opposed to $O$. universa) we compare photosynthesis rates (nmol $\mathrm{O}_{2} \mathrm{~h}^{-1}$ foraminifer ${ }^{-1}$ ) of O. universa (Rink et al., 1998) and A. lessonii (Walker 2004). Rink et al. (1998) reported a net photosynthesis of $8.72 \mathrm{nmol} \mathrm{O}_{2} \mathrm{~h}^{-1}$ for $O$. universa with a shell diameter of $554 \mu \mathrm{m}$ at $700 \mu \mathrm{mol}$ photons $\mathrm{m}^{-2} \mathrm{~s}^{-1}$. The photosynthesis data for A. lessonii in the study of Walker (2004) is normalized to the surface area and is $\sim 3.5 \mathrm{nmol} \mathrm{O}_{2} \mathrm{~s}^{-1} \mathrm{~mm}^{-2}$ at $700 \mu \mathrm{mol}$ photons $\mathrm{m}^{-2} \mathrm{~s}^{-1}$ (Fig. 19 in the study of Walker, 2004). Based on the round shape (sphere) of O. universa we first calculated the surface area $\left(A=4 \pi r^{2}\right)$ of the sphere using a shell diameter of $554 \mu \mathrm{m}$ and then normalize the photosynthesis rate to $\mathrm{s}^{-1} \mathrm{~mm}^{-2}$ as performed by Walker (2004). The comparison between the photosynthesis of $O$. universa $\left(32557 \mathrm{nmol} \mathrm{O}_{2} \mathrm{~s}^{-1} \mathrm{~mm}^{-2}\right)$ and A. lessonii $\left(3.5 \mathrm{nmol} \mathrm{O}_{2} \mathrm{~s}^{-1} \mathrm{~mm}^{-2}\right.$ ) shows that symbiont $\mathrm{O}_{2}$ production and therefore photosynthesis is lower for A. lessonii. Walker (2004) showed that in A. lessonii photosynthesis reaches its maximum at $170 \mu \mathrm{mol}$ photon $\mathrm{m}^{-2} \mathrm{~s}^{-1}$. We used 
120 umol photons $\mathrm{m}^{-2} \mathrm{~s}^{-1}$ which might have led to weak light limitation, further decreasing $\mathrm{O}_{2}$ production. Thus it is likely that $\mathrm{O}_{2}$ production in our A. lessonii specimens was at least 3 orders of magnitude lower than in the $O$. universa specimens analysed by Hönisch et al. (2003) and Zeebe et al. (2003). We hypothesize that respiration and calcification (counteracting photosynthesis) are of relative greater importance in A. lessonii than in $O$. universa. The latter assumption explains why $\delta^{11} \mathrm{~B}$ values of $A$. lessonii are closer to symbiont-barren species than the ones of $O$. universa.

In benthic foraminifers without symbionts (Neogloboquadrina dutertrei, Cibicidoides mundulus, Cibicidoides wuellerstorfi) studied so far a lighter $\delta^{11} \mathrm{~B}$ is observed than for planktonic species (Foster, 2008; Rae et al., 2011) due to a lower $\mathrm{pH}$ of the growth habitat of benthic foraminifers in deeper waters. Respiration and calcification of benthic foraminifers are the dominant processes leading to an acidification in the microenvironment. In support of this inference Glas et al. (2012) showed that the microenvironment $\mathrm{pH}$ of the symbiont-barren benthic species Ammonia spec. is, during chamber formation, ca. 0.65 lower than bulk seawater.

\section{The role of $\mathrm{B}(\mathrm{OH})_{3}$}

The incorporation of $\mathrm{B}(\mathrm{OH})_{3}$ could modify foraminiferal $\delta^{11} \mathrm{~B}$ (Klochko et al., 2009). This B species always has a heavier isotopic composition than $\mathrm{B}(\mathrm{OH})_{4}^{-}$. Therefore, additional incorporation of $\mathrm{B}(\mathrm{OH})_{3}$ would result in heavier $\delta^{11} \mathrm{~B}$ of the foraminifers. Assuming that $\mathrm{B}(\mathrm{OH})_{3}$ incorporation is positively correlated to $\mathrm{B}(\mathrm{OH})_{3}$ concentration of seawater, the foraminifers from the $\mathrm{pH} 8.6$ treatment should display the lightest $\delta^{11} \mathrm{~B}$. Contrariwise, this treatment features the heaviest $\delta^{11} \mathrm{~B}$. Therefore, incorporation of $\mathrm{B}(\mathrm{OH})_{3}$ appears to be unlikely.

\subsubsection{The variability in $\delta^{11} \mathrm{~B}$}

A significant variability in $\delta^{11} \mathrm{~B}$ between specimens from the same treatment was reported by Rollion-Bard and Erez (2010). These authors described $\Delta \delta^{11} \mathrm{~B}$ (the difference between the heaviest and lightest $\delta^{11} \mathrm{~B}$ values) to be $\mathrm{pH}$ dependent in Amphistegina lobifera. In their study the $\Delta \delta^{11} \mathrm{~B}$ increased from $4.7 \%$ o for foraminifers cultured at a $\mathrm{pH}$ of 8.45 to $12.2 \%$ o for foraminifers cultured at a $\mathrm{pH}$ of 7.9 . This variability is explained in terms of a calcification mechanism based on sea water vacuolization. It should be noted that the spot size of the analytical method they used to measure the $\delta^{11} \mathrm{~B}$ of the test (secondary ion mass spectrometry (SIMS)) was $\sim 30 \mu \mathrm{m}$. This would require that areas, of at least this size, exist within the test, which are formed from vacuoles of the same $\mathrm{pH}$. The latter is unlikely since the authors suggest themselves that the vacuoles cover a $\mathrm{pH}$ range starting at the bulk $\mathrm{pH}$ and ending with $\mathrm{pH}$ 9. Since in their study only a small portion of the test was grown under experimental conditions, the question arises whether the determined $\Delta \delta^{11} \mathrm{~B}$ would be the same if the whole test had been grown under experimental conditions. Furthermore, the hypothesis that seawater vacuolization is the only source for calcification in foraminifers is controversially discussed (Nehrke et al., 2013). We calculated $\Delta \delta^{11} \mathrm{~B}$ from our data as done in the study of Rollion-Bard and Erez (2010). The $\Delta \delta^{11} \mathrm{~B}$ are $5.82 \%$ (pH_8.1 $\left.1^{160}\right), 5.26 \%$ o $\left(\mathrm{pH} \_8.1^{260}\right), 5.21 \%$ o $\left(\mathrm{pH} \_8.1^{540}\right), 6.17 \%$ (pH_8.1640), 6.4\%o(pH_8.6 $\left.{ }^{640}\right)$ and $5.07 \%$ (pH_7. $9^{260}$ ). For a change of $0.5 \mathrm{pH}$ unit RollionBard and Erez (2010) report a change in $\delta^{11} \mathrm{~B}$ by $6.5 \%$ o which is clearly not supported by our results. A change of $0.5 \mathrm{pH}$ unit, as shown by the comparison of the 8.1_pH* (average $\Delta \delta^{11} \mathrm{~B}$ ) and $\mathrm{pH} \_8.6^{640}$ treatments exhibits a shift of $\delta^{11} \mathrm{~B}$ by only $0.79 \%$ and is lower than the error of a single foraminiferal measurement (2RSE, Eq. (S3), in the Supplement). Based on the $\Delta \delta^{11} \mathrm{~B}$ in our treatments (see above) we do not observe a correlation between $\Delta \delta^{11} \mathrm{~B}$ and $\mathrm{pH}$ in $A$. lessonii.

We discussed above several mechanisms that could cause the offset of $\delta^{11} \mathrm{~B}$ of $A$. lessonii from the theoretical value expected under the assumption that only $\mathrm{B}(\mathrm{OH})_{4}^{-}$is taken up into the test. Even though a combination of these mechanisms could explain the observed offset, they would have to operate with different magnitudes in different specimens (even for specimens from exactly the same treatment) to be in accordance with the observed variability. The latter is very unlikely and therewith no explanation on the observed offset can be given at this point. However, it is interesting to notice that for all experimental conditions the same variability between specimens is observed. Variability between specimens is documented for the uptake of other elements, e.g. like Mg. This points towards a mechanism inherent in the biomineralization process itself, which is responsible for the observed variability.

\subsection{The B / Ca of A. lessonii}

The B / Ca data of the foraminiferal tests plotted against $\mathrm{pH}$ and $\left[\mathrm{CO}_{3}^{2-}\right]$ of the culture media are shown in Fig. 5. No correlation between the plotted parameters is observed. In a culture study of Allen et al. (2011) it was shown that the $\mathrm{pH}$ of culture media and $\mathrm{B} / \mathrm{Ca}$ of foraminiferal tests are positively correlated. An increase of $\mathrm{pH}$ is associated with changes in the carbonate system: the concentrations of $\mathrm{CO}_{3}^{2-}$ and $\mathrm{B}(\mathrm{OH})_{4}^{-}$increase with increasing $\mathrm{pH}$ while the concentration of $\mathrm{HCO}_{3}^{-}$decreases. Because of these coupled processes it is, in the framework of a classical carbonate system perturbation study like the one of Allen and coworkers (2011), not possible to identify the causal agent. In a second study Allen and co-workers (2012) suggested based on data from a culture study on three different planktonic foraminiferal species using a decoupled carbonate chemistry a "competition between aqueous boron and carbon species for inclusion into the calcite lattice". To further elaborate on this hypothesis we plot our B / Ca data against several 

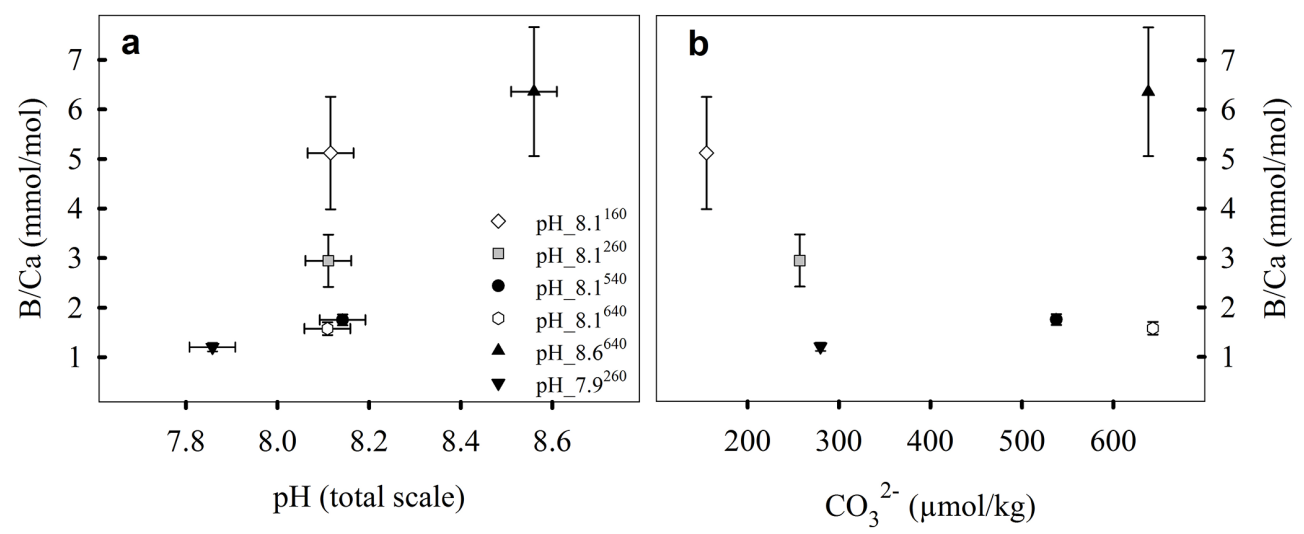

Figure 5. (a) $\mathrm{B} / \mathrm{Ca}$ plotted against $\mathrm{pH}$ of culture media and (b) $\mathrm{B} / \mathrm{Ca}$ plotted against $\left[\mathrm{CO}_{3}^{2-}\right.$ ] of culture media. Both graphs show no correlation neither with $\mathrm{pH}$ nor with $\left[\mathrm{CO}_{3}^{2-}\right]$. B / Ca data represent mean values of all measurements of foraminifers. Error bars are expressed as SD.

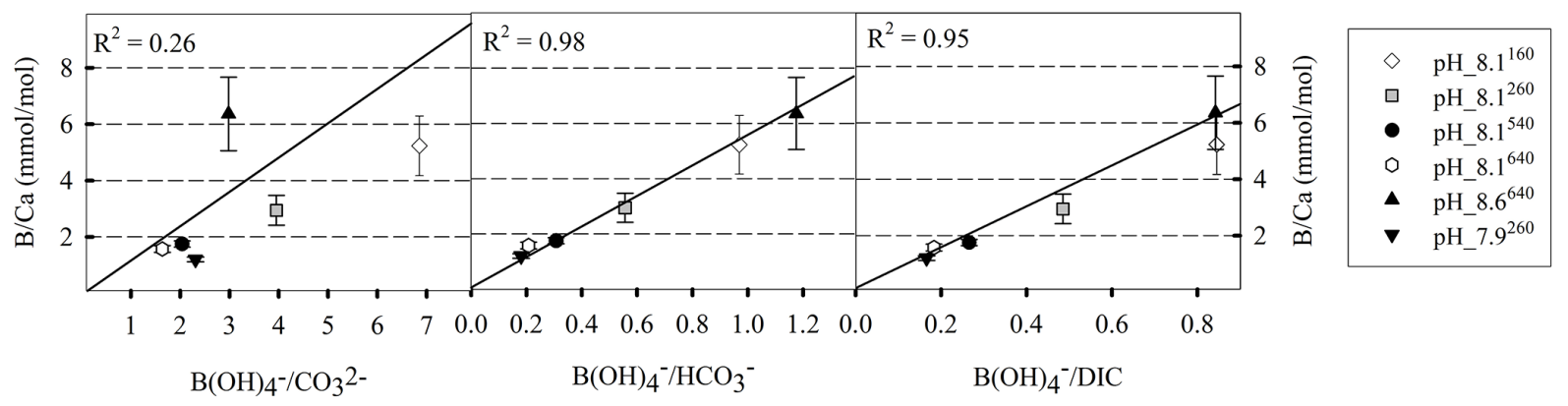

Figure 6. $\mathrm{B} / \mathrm{Ca}$ plotted against $\mathrm{B}(\mathrm{OH})_{4}^{-} / \mathrm{CO}_{3}^{2-}, \mathrm{B}(\mathrm{OH})_{4}^{-} / \mathrm{HCO}_{3}^{-}$, and $\mathrm{B}(\mathrm{OH})_{4}^{-} / \mathrm{DIC}$. The best linear regression is given when $\mathrm{B} / \mathrm{Ca}$ is plotted against $\mathrm{B}(\mathrm{OH})_{4}^{-} / \mathrm{HCO}_{3}^{-}$. B / Ca data represent mean values of all measurements. Error bars are expressed as SD.

possible candidates $\left(\mathrm{B}(\mathrm{OH})_{4}^{-} / \mathrm{CO}_{3}^{2-}, \mathrm{B}(\mathrm{OH})_{4}^{-} / \mathrm{HCO}_{3}^{-}\right.$and $\left.\mathrm{B}(\mathrm{OH})_{4}^{-} / \mathrm{DIC}\right)$. The best correlation is given when $\mathrm{B} / \mathrm{Ca}$ is plotted against $\mathrm{B}(\mathrm{OH})_{4}^{-} / \mathrm{HCO}_{3}^{-}$(Fig. 6). This is in good agreement with the data shown in the publication of Allen and co-workers (2012) for cultured G. sacculifer, G. ruber, and $O$. universa. To summarize, if $\mathrm{pH}$ and subsequently $\left[\mathrm{B}(\mathrm{OH})_{4}^{-}\right]$increase in the culture media, then $\left[\mathrm{HCO}_{3}^{-}\right]$decreases resulting in less competition for $\mathrm{B}(\mathrm{OH})_{4}^{-}$for uptake into the foraminifer's test. In a natural system the competition between $\mathrm{B}(\mathrm{OH})_{4}^{-}$and $\mathrm{HCO}_{3}^{-}$supports the underlying concept of the $\mathrm{B} / \mathrm{Ca}$ proxy: the observed linearity of foraminiferal $\mathrm{B} / \mathrm{Ca}$ and $\left[\mathrm{CO}_{3}^{2-}\right]$ can be inferred from the inverse correlated relationship between $\left[\mathrm{B}(\mathrm{OH})_{4}^{-}\right]$and $\left[\mathrm{HCO}_{3}^{-}\right]$with increasing $\mathrm{pH}$.

\section{Further observations}

At this point we would like to draw the attention of the reader to two interesting observations within our data which cannot be elaborated further within the framework of this study, but that represent an interesting basis for further investigations. (1) Since both parameters $\left(\delta^{11} \mathrm{~B}\right.$ and B / Ca) were determined simultaneously, the question arises whether a correlation between both parameters can be identified. As can be seen from Fig. 7, no preference for the incorporation of the lighter or heavier $\mathrm{B}$ isotope as a function of the $\mathrm{B}$ concentration in the tests is observed. (2) It could be observed that the standard deviation for B / Ca does show a significant increase with increasing B incorporation (Fig. 6).

\section{Conclusions}

Culture experiments based on a decoupled $\mathrm{pH}$ and $\mathrm{CO}_{3}^{2-}$ chemistry indicate that the $\delta^{11} \mathrm{~B}$ of the test of $A$. lessonii is related to $\mathrm{pH}$ whereas the $\mathrm{B} / \mathrm{Ca}$ of the foraminiferal shells shows a positive correlation with $\mathrm{B}(\mathrm{OH})_{4}^{-} / \mathrm{HCO}_{3}^{-}$. The latter observation suggests a competition between $\mathrm{B}(\mathrm{OH})_{4}^{-}$and $\mathrm{HCO}_{3}^{-}$of the culture media for $\mathrm{B}$ uptake into the test. The $\delta^{11} \mathrm{~B}$ values determined on single tests of foraminifers show an offset from the values expected if only $\mathrm{B}(\mathrm{OH})_{4}^{-}$is incorporated into the shell and a strong inter-specimen variability is observed. We evaluated potential processes responsible for these observations such as test size, vital effects, and incorporation of $\mathrm{B}(\mathrm{OH})_{3}$. However, we found that none of these pro- 

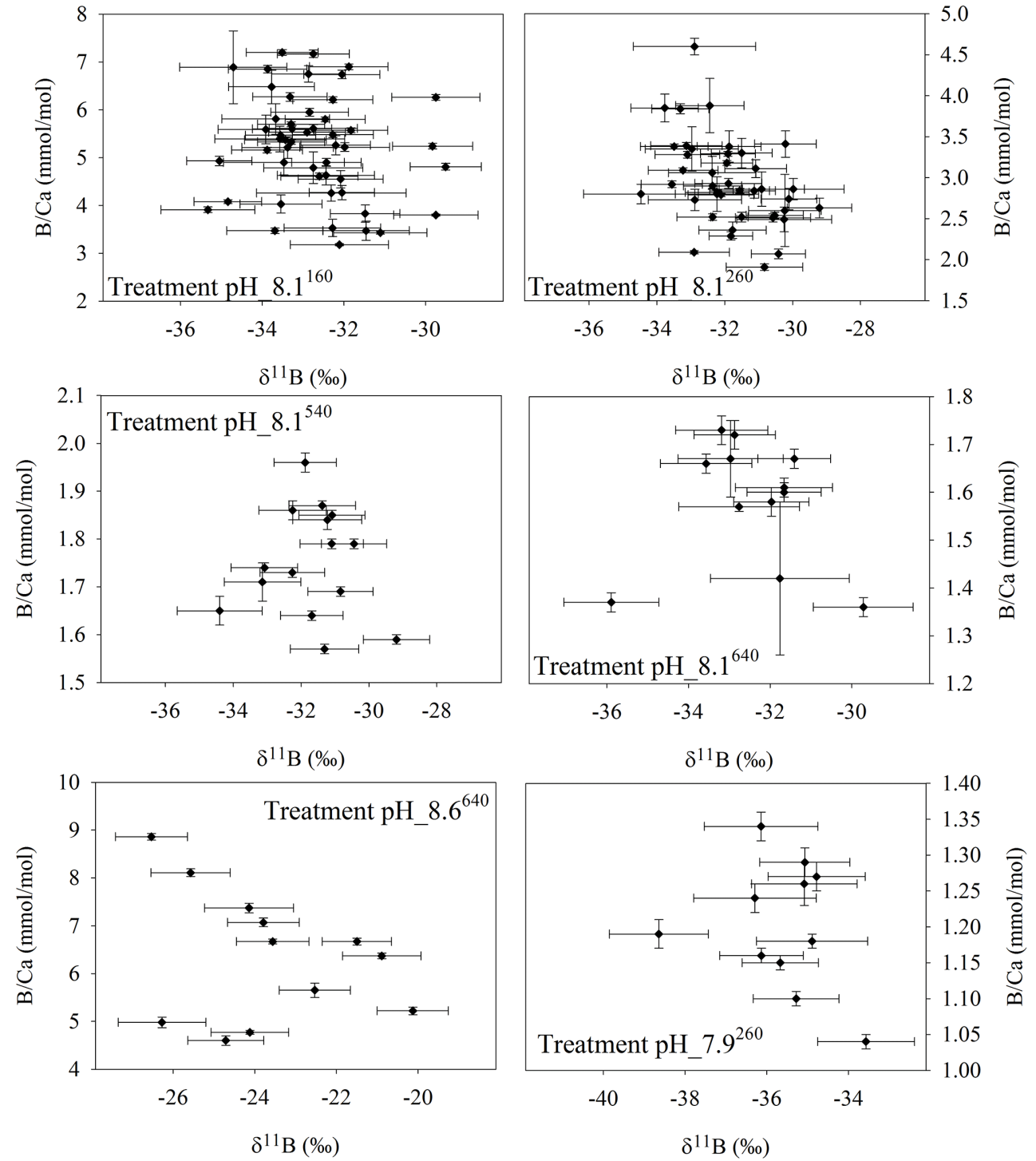

Figure 7. Single B / Ca values plotted against single $\delta^{11} \mathrm{~B}$ values. No correlation exists between the plotted parameters.

cesses, or a combination of them, can explain the observed variability in the offset between specimens.

The distribution of $\mathrm{B}$ in the tests is not homogeneous: the variability in $\mathrm{B} / \mathrm{Ca}$ increases with increasing $\mathrm{B} / \mathrm{Ca}$ in the tests. Our data show no correlation between B concentration and isotope fractionation.

The Supplement related to this article is available online at doi:10.5194/bg-12-1753-2015-supplement.
Acknowledgements. We thank Sarah Moser, Kerstin Oetjen and Tina Brenneis for assistance during the culture experiments. For analysis of DIC and elemental measurements we thank Laura Wischnewski, Jana Hölscher and Ilsetraut Stölting. We are grateful to Klaus-Uwe Richter for handling the $\mathrm{CO}_{2}$ gas-mixing system. This project was financially supported by the DFG BI 432/7-1.

Edited by: H. Kitazato 


\section{References}

Allen, K. A., Hönisch, B., Eggins, S. M., Yu, J., Spero, H. J., and Elderfield, H.: Controls on boron incorporation in cultured tests of the planktic foraminifer Orbulina universa, Earth Planet. Sc. Lett., 309, 291-301, 2011.

Allen, K. A., Hönisch, B., Eggins, S. M., and Rosenthal, Y.: Environmental controls on $\mathrm{B} / \mathrm{Ca}$ in calcite tests of the tropical planktic foraminifer species Globigerinoides ruber and Globigerinoides sacculifer, Earth Planet. Sc. Lett., 351-352, 270280, 2012.

Bradshaw, A. L., Brewer, P. G., Shafer, D. K., and Williams, R. T.: Measurements of total carbon dioxide and alkalinity by potentiometric titration in the GEOSECS program, Earth Planet. Sc. Lett., 55, 99-115, 1981.

Brown, R. E., Anderson, L. D., Thomas, E., and Zachos, J. C.: A core-top calibration of $\mathrm{B} / \mathrm{Ca}$ in the benthic foraminifers Nuttallides umbonifera and Oridorsalis umbonatus: A proxy for Cenozoic bottom water carbonate saturation, Earth Planet. Sc. Lett., 310, 360-368, 2011.

Catanzaro, E. J., Champion, C. E., Garner, E. L., Marinenko, G., Sappenfield, K. M., and Shields, W. R.: Boric Acid. Isotopic, and Assay Standard Reference Materials, Nat. Bur. Stand. (U.S.) Spec. Publ., 260-17, 70, 1970.

Dickson, A. G., Sabine, C. L., and Christian, J. R. (Eds.): Guide to Best Practices for Ocean $\mathrm{CO}_{2}$ Measurements, PICES Special Publication 3, 191, 2007.

Ernst, S., Janse, M., Renema, W., Kouwenhoven, T., Goudeau, M.L., and Reichart, G.-J.: Benthic foraminifera in a large indopacific coral reef aquarium, J. Foramin. Res., 41, 101-113, 2011.

Fietzke, J., Heinemann, A., Taubner, I., Bohm, F., Erez, J., and Eisenhauer, A.: Boron isotope ratio determination in carbonates via LA-MC-ICP-MS using soda-lime glass standards as reference material, J. Anal. Atom. Spectrom., 25, 1953-1957, 2010.

Foster, G. L.: Seawater $\mathrm{pH}, p \mathrm{CO}_{2}$ and $\left[\mathrm{CO}_{2}-3\right]$ variations in the Caribbean Sea over the last 130 kyr: A boron isotope and B / Ca study of planktic foraminifera, Earth Planet. Sc. Lett., 271, 254 266, 2008

Foster, G. L., Pogge von Strandmann, P. A. E., and Rae, J. W. B.: Boron and magnesium isotopic composition of seawater, Geochem. Geophy. Geosy., 11, Q08015, doi:10.1029/2010GC003201, 2010.

Glas, M. S., Langer, G., and Keul, N.: Calcification acidifies the microenvironment of a benthic foraminifer (Ammonia sp.), J. Exp. Mar. Biol. Ecol., 424-425, 53-58, 2012.

Gran, G.: Determination of the equivalence point in potentiometric titrations Part II, Analyst, 77, 661-671, 1952.

Hemming, N. G. and Hanson, G. N.: Boron isotopic composition and concentration in modern marine carbonates, Geochim. Cosmochim. Ac., 56, 537-543, 1992.

Henehan, M. J., Rae, J. W. B., Foster, G. L., Erez, J., Prentice, K. C., Kucera, M., Bostock, H. C., Martínez-Botí, M. A., Milton, J. A., Wilson, P. A., Marshall, B. J., and Elliott, T.: Calibration of the boron isotope proxy in the planktonic foraminifera Globigerinoides ruber for use in palaeo- $\mathrm{CO}_{2}$ reconstruction, Earth Planet. Sc. Lett., 364, 111-122, 2013.

Hönisch, B. and Hemming, N. G.: Ground-truthing the boron isotope-paleo-pH proxy in planktonic foraminifera shells: Partial dissolution and shell size effects, Paleoceanography, 19, PA4010, doi:10.1029/2004PA001026, 2004.
Hönisch, B., Bijma, J., Russell, A. D., Spero, H. J., Palmer, M. R., Zeebe, R. E., and Eisenhauer, A.: The influence of symbiont photosynthesis on the boron isotopic composition of foraminifera shells, Mar. Micropaleontol., 49, 87-96, 2003.

Hoppe, C. J. M., Langer, G., Rokitta, S. D., Wolf-Gladrow, D. A., and Rost, B.: Implications of observed inconsistencies in carbonate chemistry measurements for ocean acidification studies, Biogeosciences, 9, 2401-2405, doi:10.5194/bg-9-2401-2012, 2012.

Kaczmarek, K., Horn, I., Nehrke, G., and Bijma, J.: Simultaneous determination of $\delta^{11} \mathrm{~B}$ and $\mathrm{B} / \mathrm{Ca}$ ratio in marine biogenic carbonates at nano gram level, Chem. Geol., 392, 32-42, 2015.

Kasemann, S., Meixner, A., Rocholl, A., Vennemann, T., Rosner, M., Schmitt, A. K., and Wiedenbeck, M.: Boron and Oxygen Isotope Composition of Certified Reference Materials NIST SRM 610/612 and Reference Materials JB-2 and JR-2, Geostandard. Newslett., 25, 405-416, 2001.

Klochko, K., Kaufman, A. J., Yao, W., Byrne, R. H., and Tossell, J. A.: Experimental measurement of boron isotope fractionation in seawater, Earth Planet. Sc. Lett., 248, 276-285, 2006.

Klochko, K., Cody, G. D., Tossell, J. A., Dera, P., and Kaufman, A. J.: Re-evaluating boron speciation in biogenic calcite and aragonite using 11B MAS NMR, Geochim. Cosmochim. Ac., 73, 1890-1900, 2009.

le Roux, P. J., Shirey, S. B., Benton, L., Hauri, E. H., and Mock, T. D.: In situ, multiple-multiplier, laser ablation ICP-MS measurement of boron isotopic composition $(\delta 11 \mathrm{~B})$ at the nanogram level, Chem. Geol., 203, 123-138, 2004.

Longerich, H. P., Jackson, S. E., and Gunther, D.: Inter-laboratory note. Laser ablation inductively coupled plasma mass spectrometric transient signal data acquisition and analyte concentration calculation, J. Anal. Atom. Spectrom., 11, 899-904, 1996.

Misra, S., Owen, R., Kerr, J., Greaves, M., and Elderfield, H.: Determination of $\delta^{11} \mathrm{~B}$ by HR-ICP-MS from Mass Limited Samples: Application to Natural Carbonates and Water Samples, Geochim. Cosmochim. Ac., 140, 531-552, 2014.

Nehrke, G., Keul, N., Langer, G., de Nooijer, L. J., Bijma, J., and Meibom, A.: A new model for biomineralization and traceelement signatures of Foraminifera tests, Biogeosciences, 10, 6759-6767, doi:10.5194/bg-10-6759-2013, 2013.

Rae, J. W. B., Foster, G. L., Schmidt, D. N., and Elliott, T.: Boron isotopes and $\mathrm{B} / \mathrm{Ca}$ in benthic foraminifera: Proxies for the deep ocean carbonate system, Earth Planet. Sc. Lett., 302, 403-413, 2011.

Rink, S., Kühl, M., Bijma, J., and Spero, H. J. Microsensor studies of photosynthesis and respiration in the symbiotic foraminifer Orbulina universa, Mar. Biol., 131, 583-595, 1998.

Rollion-Bard, C. and Erez, J.: Intra-shell boron isotope ratios in the symbiont-bearing benthic foraminiferan Amphistegina lobifera: Implications for $\delta 11 \mathrm{~B}$ vital effects and paleo-pH reconstructions, Geochim. Cosmochim. Ac., 74, 1530-1536, 2010.

Sanyal, A., Hemming, N. G., Broecker, W. S., Lea, D. W., Spero, H. J., and Hanson, G. N.: Oceanic pH control on the boron isotopic composition of foraminifera: Evidence from culture experiments, Paleoceanography, 11, 513-517, 1996.

Sanyal, A., Bijma, J., Spero, H., and Lea, D. W.: Empirical relationship between $\mathrm{pH}$ and the boron isotopic composition of Globigerinoides sacculifer: Implications for the boron isotope paleopH proxy, Paleoceanography, 16, 515-519, 2001. 
Spivack, A. J. and Edmond, J. M.: Boron isotope exchange between seawater and the oceanic crust, Geochim. Cosmochim. Ac., 51, 1033-1043, 1987.

Tripati, A. K., Roberts, C. D., Eagle, R. A., and Li, G.: A 20 million year record of planktic foraminiferal B / Ca ratios: Systematics and uncertainties in pCO2 reconstructions, Geochim. Cosmochim. Ac., 75, 2582-2610, 2011.

Vogl, J. and Rosner, M.: Production and Certification of a Unique Set of Isotope and Delta Reference Materials for Boron Isotope Determination in Geochemical, Environmental and Industrial Materials, Geostand. Geoanal. Res., 36, 161-175, 2012.
Walker, R. A.: Photosynthesis and respiration in five species of benthic foraminifera that host algal endosymbionts, Master thesis, University of South Florida, 2004.

Yu, J., Elderfield, H., and Hönisch, B.: B / Ca in planktonic foraminifera as a proxy for surface seawater $\mathrm{pH}$, Paleoceanography, 22, PA2202, doi:10.1029/2006PA001347, 2007.

Zeebe, R. E. and Wolf-Gladrow, D. A.: $\mathrm{CO}_{2}$ in seawater: equilibrium, kinetics, isotopes, Elsevier Science B. V., Amsterdam, 2001.

Zeebe, R. E., Wolf-Gladrow, D. A., Bijma, J., and Hönisch, B.: Vital effects in foraminifera do not compromise the use of $\delta 11 \mathrm{~B}$ as a paleo-pH indicator: Evidence from modeling, Paleoceanography, 18, 1043, doi:10.1029/2003PA000881, 2003. 